Journal of Southeast Asian Human Rights, Vol. 3 No. 2 December 2019 pp. 317 - 343

doi: 10.19184/iseahr.v\%vi\%i.13465

(C) University of Jember \& Indonesian Consortium for Human Rights Lecturers

\title{
The Long March in the New Era: Filling Implementation Gaps between Chinese Municipal Law and the International Human Rights Law on Non- Discrimination
}

\author{
Qinxuan Peng \\ Wuhan University Institute of International Law \\ Email: pengqinxuan@hotmail.com
}

\begin{abstract}
China has entered a New Era with an aspiration to safeguard human rights through law. However, implementation gaps are found when comparing the current Chinese domestic laws on non-discrimination with the requirements set by international human rights treaties and international labour standards on eliminating discrimination in the labour market. This article illustrates how rural migrant workers are an underprivileged group in Chinese society, emphasizing the inferior treatment they experience due to their agricultural hukou residential status in urban areas. The study identifies several implementation gaps between the international standards and the Chinese domestic legal system on non-discrimination, serving as the very first step to eradicate de facto and de jure discrimination and to achieve Legal Protection of Human Rights in the New Era.
\end{abstract}

Keywords: New Era, non-discrimination, implementation gaps, multiple discrimination, legal protection of human rights

\section{INTRODUCTION}

In 2017, President Xi Jinping announced that China had entered a New Era, ${ }^{1}$ one marked by the inclusivity of legal protection of human rights (Renquan Fazhihua Baozhang). During many of his public speeches, President Xi Jinping mentioned that the Communist Party is resolved to promote "comprehensive development of human beings", and it is necessary to "enhance legal protection of human rights and to secure people's right and freedom according to the law". ${ }^{2}$ The 2017 White Paper- New

1 "Full text of Xi Jinping's report at 19th CPC National Congress - China - Chinadaily.com.cn", China Daily (4 November 2019),online: Chinadailycomcn <http://www.chinadaily.com.cn/china/19thcpc nationalcongress/2017-11/04/content_34115212.htm>.

2 Ibid. 
Progress in the Legal Protection of Human Rights in China also claimed that "the rule of law is a symbol of human progress, and serves as the guarantee for ensuring human rights," and that the Party and the government are determined to "strengthen legal protection of human rights in all areas, ensure that the Chinese people fully enjoy their rights and freedoms, achieve social fairness and justice, and promote overall human development and social progress." ${ }^{3}$ In the 2017 Report on The Work of The Supreme People's Court, His Chief Justice Zhou Qiang declared an effort "to enhance judicial protection on human rights" and "to secure legitimate procedural rights of the defendant and the victim during the litigation" as the guiding principles of work in the court system. ${ }^{4}$ These official resolutions illustrate China's great ambition to improve the legal basis for human rights protection in society.

In the Chinese New Era, instead of regarding human rights as a taboo subject, China proactively promotes its own philosophy of human rights into the international community, which is carried out through United Nations mechanisms such as Security Council and Human Rights Council, South-South Human Rights Cooperation, bilateral and multi-lateral international negotiations regarding environmental protection. For example, President Xi Jinping's ideal of "constructing a community of a shared future for mankind" has been incorporated into UN Security Council Resolutions ${ }^{5}$ and UN Human Rights Council documents. ${ }^{6}$ On 7 December 2017, the first "South-South Human Rights Forum" was held in Beijing, organized by the State Council Information Office of the People's Republic of China and the Ministry of Foreign Affairs of the People's Republic of China. They presented the Beijing Declaration ${ }^{7}$ for thesouthern resolution of international human rights cooperation.

Despite China playing an increasingly progressive role in the international human rights discourse since the New Era, the legal protection of human rights still faces a long journey ahead given the distance between the Chinese municipal laws on nondiscrimination and the requirements set by international human rights treaties and international labour conventions, most of which are ratified by China. ${ }^{8}$

This study uses the case of rural migrant workers to examine the de facto and de

3 The State Council Information Office of the People's Republic of China, New Progress in the Legal Protection of Human Rights in China (Beijing: 2017).

4 The Supreme People's Court of the People's Republic of China, Report On the Work of the Supreme People's Court (Beijing: 2017).

5 See for example, Resolution concerning the situation in Afghanistan, UNSC, S/RES/2344 (2017).

6 See Promoting mutually beneficial cooperation in the field of human rights, UNHRC, A/HRC/37/L.36 (2018).

7 See Ying Peng, "Full text of Beijing Declaration adopted by the First South-South Human Rights Forum", Xinhua News (8 December 2017), online: <http://www.xinhuanet.com/english/201712/08/c_136811775.htm>.

8 China has ratified 26 international human rights treaties and 26 ILO conventions. 
jure discrimination they face in their daily work and lives. The study showcases the implications of the existing IHRL/ILO standards on non-discrimination, and identifies implementation gaps between the international standards and the purported corresponding Chinese domestic laws accordingly. Understanding where improvement is needed is the very first step in ensuring authentic legal protection of human rights in the New Era for all without discrimination.

\section{NO COUNTRY FOR THE LOW-END? A CASE STUDY OF DE FACTO DISCRIMINATION AGAINST RURAL MIGRANT WORKERS}

Afire in the Daxing District of Beijing on 18 November $2017^{9}$ sparked extensive public discourse in China over the dire situation of the 'low-end population' ( diduan renkoul $)^{10}$ which refers to rural migrant workers who perform low-paid jobs in urban areas. " The term 'low-end population', politically incorrect as it is, has been disused in the official discourse later on. ${ }^{12}$ Yet there is an inconvenient truth that cannot be ignored: the low-paid migrant workers still live in the urban areas as second-class citizens. ${ }^{13}$ To stop using the expression 'low-end population' does not necessarily bring equality to these people but may eventually obscure them from public attention. Until today, no public discussions over their situation or legitimate rights exist. Essentially, "the low-end" are rendered invisible.

However, the term "low-end population" reveals only a part of the picture that is the vast land of inequality in China. With China's unprecedented urbanization and lingering hukou institution ${ }^{14}$, the de facto discrimination against half of the urban population prevails. ${ }^{15}$ The household registration system, also known as the hukou system, is a Chinese-specific social institution that registers each household according

$9 \quad$ "Beijing Housing Block Fire: Nineteen People Killed", BBC (19 November 2017), online: <http://www.bbc.com/news/world-asia-china-42043640>.

10 "The Making of the Low-end Population", China Media Project (30 November 2017), online: <http://chinamediaproject.org/2017/11/30/the-official-origins-of-low-end-population/>.

11 "A Safety Campaign after the Fire in Daxing District of Beijing, Official Media Denied Evacuation of Low-End Population", BBC Chinese (24 November 2017), online: www.bbc.com/zhongwen/simp/world-42113608.

12 See "Sensitive Word of the Week: Low-end Population", China Digital Times (30 November 2017), <chinadigitaltimes.net/2017/11/sensitive-word-week-low-end-population/>.

13 See Qinxuan Peng, "No Country for the Low-end? - An Intersectional Analysis of the Status of Migrant Women Workers as Domestic Helpers and Relevant Laws in China", (2019)26 International Journal on Minority and Group Rights, 1-25, at 2.

14. Hukou, a Chinese household registration system that divides the entire population into agricultural household and non-agricultural household.

15 There is a massive migration into the urban areas that takes up half of the urban population, see Jianfa Shen and Wei Xu, "Migration and Development in China: Introduction", (2016)16:3 China Review at $1-7$. 
to its rural or urban residence, which results in agricultural hukou for rural residence and non-agricultural hukou for urban residence. ${ }^{16}$ The institution also categorizes each city as 'first-tier' until 'third-tier' and 'late-developed', only reinforcing the structural inequalities in the migration process. ${ }^{17}$ After all, it is rather difficult for rural migrant workers to convert their agricultural hukou into urban local hukou. Similarly, it is also difficult for 'late-developed' urban hukou holders to become a 'first-tier' urban hukou holder. Consequentially, the social stratification ossifies.

To exacerbate the situation, rural migrant workers are unable to purchase a house or flat to settle down without local urban hukou, or to engage in decent formal work. ${ }^{18}$ Female rural migrant workers might as well face multiple disadvantages arising from their hukou status and their gender. ${ }^{19}$ Yet the existing Chinese municipal laws on nondiscrimination are unsystematic and cannot work effectively to address remedies for the marginalized.

Further, the situation is by no means in small scale. As is shown in the Table 1.1 below, there were more than 286 million migrant workers in China in 2017. ${ }^{20}$ This number has been constantly increasing in recent years against the background of rapid urbanization in China. ${ }^{21}$ Migrant workers comprise at least $35 \%$ of the whole work force in China, according to the data provided by the World Bank. ${ }^{22}$ Amongst these migrant workers, $52.4 \%$ are people younger than 40 years old, at the age when they are at their most productive. ${ }^{23}$ Despite the significant numbers of migrant workers and their great contribution to economic growth, there are still a huge number of people living

16 See Qinxuan Peng, "No Country for the Low-end? - An Intersectional Analysis of the Status of Migrant Women Workers as Domestic Helpers and Relevant Laws in China", (2019)26 International Journal on Minority and Group Rights at1-25, 14.

17 See Jing Song et al, "Mobility and Life Chances in Urbanization and Migration in China: Introduction, (February 2018)18.1 China Review at 2.

18 See Pu Hao and Shuangshuang Tang, "Floating or Settling Down: Effect of Rural Landholdings on the Settlement Intention of Rural Migrants in Urban China," (2015) 47 Environment and Planning, at 1979-1999.

19 See Qinxuan Peng, "Multi-layered Gaps between ILO Conventions and Chinese Legal System", Bulletin for Comparative Labour Relations-89, Kluwer Law Business, 2015, 31-48.

20 National Bureau of Statistics of People's Republic of China, The 2017 Investigation and Survey Report on the National Migrant Workers (Beijing: 27 April 2018) http://www.stats.gov.cn/tjsj/zxfb /201804/t20180427_1596389.html

21 See Pan Jiahua and Wei Houkai ed, Blue Book of Cities in China: Annual Report on Urban Development in China No.5, first edition (Beijing: Social Science Academic Press, 2012).

22 See"Labour Force," World Bank (15 February 2017), online: <http://data.worldbank.org/indicator/SL.TLF.TOTL.IN/countries> What is worth mentioning here is that the total labour force figures in China given by the World Bank included the employed and the unemployed and even the armed forces but did not include workers in the informal sector.

23 National Bureau of Statistics of People's Republic of China, The 2017 Investigation and Survey Report on the National Migrant Workers, (Beijing: 27 April 2018), online:<http://www.stats.gov.cn/tjsj/zxfb/201804/t20180427_1596389.html>. 
and working in the cities without a local urban hukou. ${ }^{24}$ These people without local hukou still experience inferior treatment in many aspects of lives compared with workers with local urban hukou in terms of employment, social welfares, medical cares and education.

\begin{tabular}{l|l|l|l|l}
\hline Year & $2014^{25}$ & $2015^{26}$ & $2016^{27}$ & $2017^{28}$ \\
\hline \begin{tabular}{l|l|l} 
Total \\
\hline$\quad$ Migrant
\end{tabular} & $168,210,000$ & $168,840,000$ & $169,340,000$ & $171,850,000$ \\
$\begin{array}{l}\text { across } \\
\text { province }\end{array}$ & & $277,470,000$ & $281,710,000$ & $286,520,000$ \\
\hline $\begin{array}{l}2 . \quad \text { Migrant } \\
\text { within } \\
\text { province }\end{array}$ & $105,740,000$ & $108,630,000$ & $92,680,000$ & $95,100,000$ \\
\hline
\end{tabular}

Table 1.1 The number of migrant workers during 2014 to 2017 in China

While they seek employement, migrant workers face overt discrimination based on their hukou status: $47.91 \%$ of college graduates were asked for a local hukou when seeking jobs; ${ }^{29}$ otherwise they would face unreasonable demands from employers such

24 See Kam Wing Chan, "The Household Registration System and Migrant Labour in China: Notes on a Debate," (2010)36:2 Population and Development Review, at 360.

25 See National Bureau of Statistics of People's Republic of China, The 2014 Investigation and Survey Report on the National Migrant Workers, (Beijing: 29 April 2015), online: <http://www.stats.gov.cn/tjsj/zxfb/201504/t20150429_797821.html>.

26 See National Bureau of Statistics of People's Republic of China, The 2015 Investigation and Survey Report on the National Migrant Workers, (Beijing: 28 April 2016), online: <http://www.stats.gov.cn/tijj/zxfb/201604/t20160428_1349713.html>.

27 See National Bureau of Statistics of People's Republic of China, The 2016 Investigation and Survey Report on the National Migrant Workers, (Beijing: 28 April 2017), online: <http://www.stats.gov.cn/tijj/zxfb/201704/t20170428_1489334.html>.

28 See National Bureau of Statistics of People's Republic of China, The 2017 Investigation and Survey Report on the National Migrant Workers, (Beijing: 28 April 2017), online: <http://www.stats.gov.cn/tijs/zxfb/201804/t20180427_1596389.html>.

29 See Constitutionalism Research Institute in China University of Political Science and Law, "The 2010 Investigation Report on the Employment Discrimination against College Graduates in 
as being charged a deposit, or having their identity documents retained as a guarantee. ${ }^{30}$ Most migrant workers earn barely the local minimum wage standards because of their difficulties in obtaining bargaining power for better working conditions, ${ }^{31}$ mostly due to their agricultural hukou status.

Without local urban hukou, migrant workers are often ineligible for basic entitlements, such as being unable to purchase a residence in the city due to the property purchase limits set by most of the urban governments since 2011. ${ }^{32}$ Most migrant workers are screened from urban-welfare system such as renting subsidies, subsidized house purchase opportunities, children's access to local schools that local hukou holders often enjoy. Large metropolitan cities like Beijing, Shanghai and Guangzhou still keep a required a student's hukou status to sit for the National College Entrance Examination (Gaokao). ${ }^{33}$ Furthermore, employers are hesitant to offer openings to 'migrant children'. Although the Cooperative Rural Medical Insurance scheme $^{35}$ has a wide coverage in rural areas, it does not cover the medical expenses incurred in cities where most migrant workers live. As a result, many of them are vulnerable in the case of any work injuries ${ }^{36}$ or occupational diseases.

Migrant workers without local hukou, generally face inferior treatment in the fields of employment, social security, health care and education. ${ }^{37}$ Such disadvantages and lack of equal opportunities based on one's household registration status are discrimination grounded on social origin ${ }^{38}$ meaning that an individual's membership of

Contemporary China," in Cai Dingjian, The Employment Discrimination in China, Current conditions and anti-Discrimination Strategies (Beijing: China Social Science Press, 2011), at 196200 .

30 See Zhang Yonghong, "Politics of Local Governance: A Systemic Perspective, Using the Implementation of Policies on the Protection of Rural Migrant Workers as an Example," (2009) 49:1 Journal of Sun Yat-sen University, Social Science Edition.

31 Zhang Huafeng, "An Economic Analysis of Residence Requirements and Employment Discrimination," in Li Weiwei and Lisa Stearns, Employment Discrimination: International Standards and National Practice (Beijing: Law Press, 2006), 508.

32 See "An Overview of the Real Estate Property Purchase Limit Policies in various cities 2018", Fang.com (22 May 2018), online: online:<https://news.fang.com/open/28524435.html >.

33 Concluding observations on the second periodic report of China, including Hong Kong, China, and Macao, China, CESCR, E/C.12/CHN/CO/2, (2014)35.

34 "Sitting in College Entrance Examination in Shanghai? You Need a Shanghai hukou First," Ifeng $\begin{array}{llll}\text { News } & (30 & \text { December } & \text { online:< }\end{array}$ http://news.ifeng.com/mainland/detail_2012_12/30/20671337_0.shtml >.

35 A collective fund raised to provide medical insurance for rural-hukou holders in China.

36 Liu Shuhong, "Only 22\% Of Rural Migrant Workers Are Covered by Work Injury Insurance," Legal Daily (15 August 2009), online: <http://www.legaldaily.com.cn/0801/200908/15/content_1138656.htm>

37 Concluding observations on the second periodic report of China, including Hong Kong, China, and Macao, China, CESCR, E/C.12/CHN/CO/2 (2014) para15.

38 ILO CEACR, Direct Request to China, on Discrimination (Employment and Occupation) 
a class, socio-occupational category or caste determines his or her occupational future, either because he or she is denied access to certain jobs or activities, or is assigned only certain jobs. ${ }^{39}$ Poor working conditions, including excessive working hours and lack of sufficient breaks, are especially acute for rural migrant workers in the city areas. ${ }^{40}$ At the same time, the locally supported social security, including basic retirement pensions, basic medical care, and the minimum living standard scheme (di bao) are not equally accessible to workers with agricultural hukou. ${ }^{41}$ Finally, migrant workers do not have equal access to subsidized medical care and have to pay disproportionately higher premiums for medical insurance and medical costs, in comparison with their urban counterparts. ${ }^{42}$

\section{IHRL/ILO STANDARDS ON NON-DISCRIMINATION: AN OVERVIEW}

The principle of promoting equality and eliminating discrimination is pivotal to all international human rights instruments. ${ }^{43} \mathrm{As}$ is prescribed in the preamble of the Charter of the United Nations, the faith in "the equal rights of men and women" is reaffirmed as the very essential idea of establishing this international platform to "promote and encourage respect for human rights and for fundamental freedoms for all without distinction as to race, sex, language, or religion". "Being the birthplace of international human rights instruments, the 1948 Universal Declaration of Human Rights explicitly states that "everyone is entitled to all the rights and freedoms set forth in this Declaration, without distinction of any kind, such as race, colour, sex, language, religion, political or other opinion, national or social origin, property, birth or other status".

A similar mandate to ensure equality and eliminate discrimination is also found in the ILO Constitution and other ILO declarations made since that organisation's establishment. The principle of "equal remuneration for work of equal value" was enshrined in the preamble of the 1919 ILO Constitution, which constituted Part XIII

Convention, 1958 (No. 111) (2012), 102 ILC Sess, at paras. 1 and 7.

39 Discrimination based on social origin, ibid.

40 Concluding observations: People's Republic of China, including Hong Kong and Macao, CESCR, E/C.12/1/Add.107 (2005) para.24.

41 Concluding observations on the second periodic report of China, including Hong Kong, China, and Macao, China, CESCR, E/C.12/CHN/CO/2 (2014) para.24.

42 Ibid, para.33.

43 General Comment No. 2 on the rights of migrant workers in an irregular situation and members of their families, UNCMW, CMW/C/GC/2, (2013) para.18.

44 Charter of the United Nations, 1 UNTS XVI, UN (1945) 1.

45 Universal Declaration of Human Rights, GA Res 217 A (III), UNGA, UN Doc A/810(1948)2. 
of the Treaty of Versailles. ${ }^{46}$ Later on, the 1944 Declaration concerning the aims and purposes of the International Labour Organisation, declares that "all human beings, irrespective of race, creed or sex, have the right to pursue both their material well-being and their spiritual development in conditions of freedom and dignity, of economic security and equal opportunity". ${ }^{47}$ In the 1998 ILO Declaration on Fundamental Principles and Rights at Work, "elimination of discrimination in respect of employment and occupation" has been explicitly included as one of the four fundamental categories of principles to be respected and promoted by the member states "whether or not they have ratified the relevant Conventions". ${ }^{48}$

Given the importance of ensuring equality and eliminating discrimination, how is discrimination defined in the IHRL/ILO normative system? Although the content and scope of equality and discrimination have not yet been finally agreed upon in the international human rights law arena, ${ }^{49}$ some valuable implications can be extracted from the existing common denominators in the IHRL/ILO convention system as the benchmark for domestic legislation to eliminate discrimination as below.

1. Each convention, for the sake of its object and purpose, lays out a clear definition of discrimination. For example, the Convention on the Elimination of all Forms of Discrimination Against Women (CEDAW) clearly defines "discrimination against women" as "any distinction, exclusion or restriction made on the basis of sex which has the effect or purpose of impairing or nullifying the recognition, enjoyment or exercise by women, irrespective of their marital status, on a basis of equality of men and women, of human rights and fundamental freedoms in the political, economic, social, cultural, civil or any other field". Understandings can be drawn from the definition that as long as unreasonable distinctive treatment is made on the basis of sex, no matter whether it has an objective effect or subjective purpose of impairing women's entitlement to human rights and fundamental freedoms, such different treatment can be regarded as "discrimination against women". Additionally, the antidiscrimination principle is widely applied in all social fields including political, economic, social, cultural and civil or any other similar field, which expands the possibilities of including domestic violence and other gender discrimination in the private sphere as discrimination.

2. Direct discrimination and indirect discrimination are differentiated and clarified in the IHRL/ILO standards system. According to ICESCR General Comment No.16, direct discrimination occurs when "an individual is treated less favourably than

46 Constitution of the International Labour Organisation, ILO (1919).

47 Declaration Concerning the Aims and Purposes of the International Labour Organisation, ILO (1944).

48 Declaration on Fundamental Principles and Rights at Work, ILC, 86 Sess, (1998).

49 A. Bayefsky, "The Principle of Equality or Non-discrimination in International Law," (1990)11: Human Rights Journal, at 2. 
another person in a similar situation for a reason related to a prohibited ground" without reasonable justification. ${ }^{50}$ Several elements must be examined here. First, the existence of unfavourable treatment is the basis of discriminatory action. Second, when claiming unfavourable treatment, a comparator in a similar circumstance needs to be identified. For example, comparing male workers' wages with women workers' wages in a similar context. Finally, the reason for such unfavourable situation is based on a protected ground, such as sex, race, age, disability and other social categories, that is prohibited from being discriminated against by law.

Indirect discrimination, however, is related to "measures which are not discriminatory at face value but are discriminatory in fact and effect". ${ }^{52}$ As is interpreted by the ICESCR General Comment, indirect discrimination occurs when apparently neutral policies have an objective effect of unequal treatment on persons with characteristics that must not form the ground of discrimination. ${ }^{53}$ In this definition, whether or not there is discriminatory intent behind such measures that cause discrimination is irrelevant in determining indirect discrimination. In fact, even some innocent, good faith measures may constitute indirect discrimination if they result in disproportionately impacting a certain group of people with detrimental effect. ${ }^{54}$ This means that intention, be it bad or benign, is not a precondition of determining indirect discrimination; the detrimental effect to a certain group of people is the key factor.

Regarding employment, the ILO Declaration on Fundamental Principles and Rights at Work has a defines indirect discrimination as instances "where rules or practices appear on the surface to be neutral but in practice lead to exclusions". ${ }^{55}$ The declaration offers an example in employment specifically in mandating a height requirement which could disproportionately exclude women. This might constitute indirect discrimination, unless such height was absolutely essential in performing

50 General Comment No. 16: The Equal Right of Men and Women to the Enjoyment of All Economic, Social and Cultural Rights (Article 3 of the Covenant), CEACR, E/C.12/2005/4, (2005) para.12-13.

51 European Union Agency for Fundamental Rights, European Court of Human Rights, Handbook on European Non-Discrimination Law (Strasbourg: Council of Europe Publishing, 2011) 22-26.

52 Dagmar Schiek, "Indirect Discrimination", in Dagmar Schiek et al, Cases Materials and Texts on National, Supranational and International Non-discrimination Law (Oregon: Hart Publishing, 2007) $323-475$, at 340.

53 General comment No. 20: Non-discrimination in economic, social and cultural rights (Article 2, para. 2, of the International Covenant on Economic, Social and Cultural Rights), CESCR, $\mathrm{E} / \mathrm{C} .12 / \mathrm{GC} / 20(2009)$ para.10.

54 Christa Tobler, Indirect Discrimination, A case study into the Development of the Legal Concept of Indirect Discrimination under the EC Law (Antwerp, Oxford: Intersentia, 2005) 235.

55 ILO, Declaration on Fundamental Principles and Rights at Work, adopted by the International Labour Conference at its Eighty-sixth Session, Geneva, 18 June 1998. 
that particular job. ${ }^{56}$ Another example of indirect discrimination against women is when a certain exclusion from benefits is imposed upon part-time workers, because taking part-time work is particularly common among women who, more often than not, take on heavy domestic responsibilities. ${ }^{57}$

3. 'Social origin' is listed as one of the prohibited grounds for discrimination. Social origin, mentioned as a prohibited ground in many IHRL/ILO documents, such as Article 2 of UDHR, ${ }^{58}$ Article 2 of ICCPR $^{59}$ and Article 2 of ICESCR ${ }^{60}$ and Article 1 of ILO C111, ${ }^{61}$ refers to a person's inherited social status, which is has historically been linked to descent-based discrimination under birth and economic and social status. $^{62}$ The 2012 ILO General Survey further explained that "discrimination and lack of equal opportunities based on social origin refer to situations in which an individual's membership of a class, socio-occupational category or caste determines his or her occupational future, either because he or she is denied access to certain jobs or activities, or is assigned only certain jobs". ${ }^{63}$ The ILO CEACR Direct Request to China points out that privileges are attached to non-agricultural hukou registration whilst poorer conditions are experienced by those without such status, which constitutes discrimination based on social origin. ${ }^{64}$

4. Multiple discrimination comes under the attention of IHRL/ILO standards. Overlapping disadvantages have gradually been conceptualized as 'multiple

56 Ibid.

57 Leontine Bijleveld, "Domestic Work in The Netherlands: A Job Like No Other" (2015)1 European Equality Law Review, 51.

58 Universal Declaration of Human Rights, GA Res 217 A (III), UNGA, UN Doc A/810(1948)2.

59 International Covenant on Civil and Political Rights, 16 December 1966, 16 December 1966, GA Res 2200A (XXI) (entered into force on 23 March 1976).

60 Article 2, International Covenant on Economic, Social and Cultural Rights, 16 December 1966, GA Res 2200A (XXI) (entered into force on 3 January1976).

61 Article 1(1): 'Discrimination' includes: “(a) any distinction, exclusion or preference made on the basis of race, colour, sex, religion, political opinion, national extraction or social origin, which has the effect of nullifying or impairing equality of opportunity or treatment in employment or occupation;

(b) such other distinction, exclusion or preference which has the effect of nullifying or impairing equality of opportunity or treatment in employment or occupation as may be determined by the Member concerned after consultation with representative employers' and workers' organizations, where such exist, and with other appropriate bodies."

Convention concerning Discrimination in Respect of Employment and Occupation, ILO, C111, 25 June 1958.

62 General Comment No. 20: Non-discrimination in economic, social and cultural rights (Article 2, para. 2, of the International Covenant on Economic, Social and Cultural Rights), CESCR, E/C.12/GC/20, (2009) para.24.

63 International Labour Office, General Survey concerning fundamental Conventions concerning rights at work in light of the ILO Declaration on Social Justice for a Fair Globalization, (Geneva: ILO, 2012), 334.

64 ILO CEACR, Direct Request to China, on ILO Convention concerning Discrimination in Respect of Employment and Occupation, 1958(No. 111), 99 ILC Sess, (2010). 
discrimination', ${ }^{65}$ 'intersectional discrimination', ${ }^{66}$ 'cumulative discrimination', ${ }^{67}$ 'complex bias', 'multi-dimensional inequalities' or 'simultaneous interlocking oppressions' in the various treaty bodies' opinions. ${ }^{68}$ The ICESCR General Comment No. 20 points out that "some individuals or groups of individuals face discrimination on more than one of the prohibited grounds", and that such "cumulative discrimination has a unique and specific impact on individuals and merits particular consideration and remedying". ${ }^{69}$ In a similar vein, ICESCR General Comment No. 20 recommends "a flexible approach to the ground of 'other status", in order to incorporate other forms of differential treatment that are not "reasonably and objectively justified and are of a comparable nature to the expressly recognized grounds" in the Covenant, because discrimination takes on different forms contextually over time. Noting the unique impact of such complicated forms of discrimination against individuals, the ICESCR General Comments encourages particular consideration and appropriate remedies for it. ${ }^{70} \mathrm{~A}$ CEDAW General Recommendation also suggests specific, temporary special measures to deal with such "multiple forms of discrimination against women and its compounded negative impact on them". The CEDAW General Recommendation No. 26 points out that women migrant workers often face "intersecting forms of discrimination, suffering not only sex- and gender-based discrimination, but also xenophobia and racism", which makes them extra "vulnerable to sexual abuse, sexual harassment and physical violence, especially in those gender-segregated sectors where women predominate". These continual efforts in the international legal circle to address intersectional discrimination rightly endorse the indivisibility

65 "Multiple discrimination" is adopted by Article 6(1) in Convention on the Rights of Persons with Disabilities: resolution / adopted by the General Assembly, 24 January 2007, A/RES/61/106. "Multiple forms of discrimination" is used by General Recommendation No. 25, on article 4, paragraph 1, of the Convention on the Elimination of All Forms of Discrimination against Women, on temporary special measures, CEDAW, (2004) para.12.

66 "Intersectional discrimination" is explicitly referred to by General Recommendation No. 28 on the Core Obligations of States Parties under Article 2 of the Convention on the Elimination of All Forms of Discrimination against Women, CEDAW/C/GC/28, CEDAW, (2010) para.26.

67 "Cumulative discrimination", see General Comment No. 20: Non-discrimination in economic, social and cultural rights (Article 2, para. 2, of the International Covenant on Economic, Social and Cultural Rights), CESCR, E/C.12/GC/20, (2009) para.17.

68 Timo Makkonen, Multiple, Compound and Intersectional Discrimination: Bringing The Experiences of the Most Marginalized to the Fore, Institute for Human Rights (Turku: Åbo Akademi University Press, 2002), 9-12.

69 See General Comment No. 20: Non-discrimination in economic, social and cultural rights (Article 2, para. 2, of the International Covenant on Economic, Social and Cultural Rights), CESCR, E/C.12/GC/20, (2009) para.27.

70 Ibid, para 17.

71 See General Recommendation No. 25, on article 4, paragraph 1, of the Convention on the Elimination of All Forms of Discrimination against Women, on temporary special measures, CEDAW, (2004) para.12.

72 See General Recommendation No. 23: Political and Public Life, A/52/38, CEDAW (1997) para.20. 
of human rights to which different groups of people are entitled, despite the fact that some of the international human rights conventions seem to only address the human rights of a group of people with a singular social category. ${ }^{73}$

5. 'Equal pay for work of equal value' is further clarified by IHRL/ILO standards. For example, Article 1 (b) of ILO 100 requires an elimination of such system in the labour market by ensuring "equal pay for work of equal value for both men and women workers". ${ }^{74}$ Article 7 of ICESCR also emphasizes that women must be guaranteed "conditions of work not inferior to those enjoyed by men, with equal pay for equal work". ${ }^{75}$ Article 11 (d) of CEDAW specifically requires "equality of treatment in the evaluation of the quality of work", which means, according to Article 1(b) of ILO No. 100 Equal Remuneration Convention, "rates of remuneration established without discrimination based on sex". ${ }^{76}$

As is provided in the ILO Equal Remuneration Convention, the rates of remuneration shall not be set according to sex. It is recommended by both CEDAW General Recommendation No. 13 and Article 3(1) of ILO C100 that gender-neutral criteria on the basis of the work to be performed are to be established. ${ }^{77}$ Thus, the rate to determine the value of a certain job should be fixed on objective criteria that are free from gender bias, ${ }^{78}$ such as what is done, how it is done, risks undertaken, skills required, effort demanded, responsibilities and working conditions. ${ }^{79}$ Such a job evaluation standard goes beyond the superficial elements of similar work, but covers work which appears to be of a different nature, yet is essentially of equal value. ${ }^{80}$ For example, under some circumstances, the skill required, the stress endured and the responsibility assumed by a domestic helper is no less than the male-dominated sales work, which means that these two different work can be of equal value and can be equally remunerated. Further, the General Comment of ICESCR and ILO No.100 recommends a comprehensive

73 Lisa A. Crooms, "Indivisible Rights and Intersectional Identities or, What Do Women's Human Rights Have to Do with the Race Convention?" (1997) 619:40 Howard Law Journal, 625-626.

74 Article 1 (b), Convention concerning Equal Remuneration for Men and Women Workers for Work of Equal Value, 29 June 1951, ILO, C100.

75 Article 7 (a)(i), International Covenant on Economic, Social and Cultural Rights, 16 December 1966, GA Res 2200A (XXI) (entered into force on 3 January1976).

76 Article 1, Convention concerning Equal Remuneration for Men and Women Workers for Work of Equal Value, 29 June 1951, ILO, C100.

77 General Recommendation No. 13: Equal remuneration for work of equal value, CEDAW (1989) para3.

78 International Labour Office, General Survey concerning fundamental Conventions concerning rights at work in light of the ILO Declaration on Social Justice for a Fair Globalization, (Geneva: ILO, 2012), 291.

79 ILO CEACR, Observation concerning Equal Remuneration Convention (No. 100), ILC, 97 ILC Sess, (2008) para.4.

$80 \quad$ Ibid, para.3. 
combination of methods, including constitutional and legislative provisions, ${ }^{81}$ legally established or recognized machinery for wage determination, collective agreements between employers and workers, ${ }^{82}$ are to be adopted by the state parties. This is drawn from several aspects of international human rights law and international labour standards on non-discrimination, which are served as benchmarks in identifying implementation gaps displayed by Chinese municipal laws.

\section{IMPLEMENTATION GAPS IDENTIFIED: A LONG MARCH BETWEEN STATUS QUO AND THE IHRL/ILO STANDARDS ON NON-DISCRIMINATION}

Implementation gaps may occur during the legislation of the international human rights legal framework and its implementation in each state parties domestically. ${ }^{83}$ For the relevance of this study, 'implementation gaps' occur when states fail to pass domestic legislation, or do not establish procedures and institutions that are required to implement an international standard. ${ }^{84}$ Based on the analysed implications derived from the existing IHRL/ILO standards on non-discrimination, this section identifies several implementation gaps in the Chinese municipal legal system that mismatch the ratified international human rights treaties and conventions and their requirement on eliminating discrimination.

\section{An Absence of a Comprehensive Set of Anti-Discrimination Laws}

A case in 2016 filed in the claim of "gender discrimination in the labour market" has caught public attention. The case is about Ms. Gao Xiao (pseudonym) had always wanted to become a professional chef but was denied the opportunity to realize her dream. Ms. Gao Xiao worked hard through trainings to improve her culinary skills and had received a chef's qualification. Despite having a vast array of qualifications, she was repeatedly rejected apprenticeships in Guangdong Province despite her qualifications. The restaurant claimed that it would "only recruit male chefs". Ms. Gao Xiao was quite

81 General Comment No. 16: The Equal Right of Men and Women to the Enjoyment of All Economic, Social and Cultural Rights (Article 3 of the Covenant), 11 August 2005, CESCR, E/C.12/2005/4, para.19.

82 Article 2(2), Convention concerning Equal Remuneration for Men and Women Workers for Work of Equal Value, 29 June 1951, ILO, C100.

83 For more details of the concepts of normative gap, application gap, supervisory gap, ratification gap and implementation gap, see International Council on Human Rights Policy, Human Rights Standards: Learning from Experience (Switzerland: Versoix, 2006), 7-8.

84 Ibid, 9. 
offended by the blunt, discriminatory attitude of the restaurant. On 18 August 2015, she filed a civil case against the restaurant in the Zhuhai District Court in Guangdong City. The case was admitted by court on the same day. After a several month long appeals procedure, the Guangzhou Mediate Court in Guangdong Province decided, on 6 September 2016, that the defendants had to pay $2000 \mathrm{RMB}$ as the compensation for emotional damages, in addition to the trial fee. Furthermore, the defendant restaurant was required to issue a written apology to Ms. Gao Xiao under the supervision of the court. $^{85}$ This case was widely praised by the media as a progress because it was the first case on non-discrimination which resulted in a court decision demanding a written apology for the victim. ${ }^{86}$

The aforementioned case, together with many other discrimination cases, rightly reflected the flaws of non-discrimination laws in China. Due to the lack of clarity of discrimination law, the case-by-case way to test the legal boundary of discrimination in China is the most ineffective channel there is to solve de facto discrimination, let alone to live up to the requirements of the ratified UN and ILO convention. As Article 2 (2) of ICESCR obliges its states parties to safeguard non-discrimination in the exercise of all the rights prescribed in the Covenant, ${ }^{87}$ the obligation to ensure non-discrimination in domestic law is immediate and cross-cutting. ${ }^{88}$ Also, the scope of discrimination, as explained in the CESCR General Comment No.20, includes not only direct/indirect exclusion based on prohibited grounds that impairs rights' enjoyment, but also incitement to discriminate and harassment. ${ }^{89}$ In order to fulfil this obligation, states are urged to take action to eliminate both formal discrimination from state laws and substantive discrimination in practice. ${ }^{90}$ Meanwhile, according to the ratified ILO Convention 111, states parties are requested to undertake national policies to eliminate any discrimination and to promote equality of opportunity and treatment in respect of employment and occupation. ${ }^{91}$

There are numerous provisions which can be traced in many Chinese codes in this

85 See: "Female candidate was rejected to be employed as a chef, court ruled a written apology from the restaurant," Xinhua News (22 September 2016), online: <http://www.gd.xinhuanet.com/newscentre/2016-09/22/c_1119604273.htm>

86 See "Court ruled apology for the first time for gender discrimination case," Ifeng News (22 September 2016), online: <http://wemedia.ifeng.com/282574491706821/wemedia.shtml>

87 Article 2(2), UN General Assembly, International Covenant on Economic, Social and Cultural Rights, 16 December 1966, United Nations Treaty Series, vol. 993, p. 3.

88 UN Committee on Economic, Social and Cultural Rights (CESCR), General comment No. 20: Non-discrimination in economic, social and cultural rights (Article 2, para. 2, of the International Covenant on Economic, Social and Cultural Rights), 2 July 2009, E/C.12/GC/20, para.7.

89 Ibid.

90 General Comment No. 16: The Equal Right of Men and Women to the Enjoyment of All Economic, Social and Cultural Rights (Article 3 of the Covenant), CESCR, E/C.12/2005/4, (2005).

91 Article 2, Convention concerning Discrimination in Respect of Employment and Occupation, 25 June 1958, ILO, C111. 
respect. For example, Article 48 of the Constitution entitles women to "equal rights with men in all spheres of life, political, economic, cultural and social, and family life". ${ }^{92}$ Also, Article 12 of Labour Law prohibits discrimination against workers "due to their ethnic community, race, sex, or religious belief". ${ }^{93}$ But other than such declaratory provisions, no more details can be found in any legal documents to help the judge to determine what discrimination is. What constitutes discrimination and what are the exceptions? Who bears the burden of proof ${ }^{94}$ What are the remedies for those who are discriminated against? Are there punitive damages or compensative damages in such situations and to what extend? All questions are unclear according to the current Chinese laws.

Indeed, when examining the treaty obligation and the Chinese situation, the CESCR Concluding Observation to China in 2014 has pointed out an existing gap in this respect that, ${ }^{95}$ "Despite the incorporation of the principle of non-discrimination in

the State Party's ( China's ) Constitution and in other laws, the Committee regrets that the State party does not have a comprehensive anti-discrimination law that protects all marginalized and disadvantaged individuals and groups in their enjoyment of economic, social and cultural rights." China is urged to take all necessary measures to "adopt a comprehensive set of anti-discrimination laws to combat all forms of discrimination suffered by all disadvantaged individuals and groups" ${ }^{96}$

\section{Unclear Definition of Discrimination in the Legal System}

Discrimination, according to definitions in the international conventions, means any forms of distinction, exclusion, restriction or preference or differential treatment, which has the intention or effect of nullifying or impairing the recognition, enjoyment or exercise of certain rights, based on the prohibited grounds of discrimination such as gender, race, disability, ethnicity and etc. ${ }^{97}$ Discrimination may also manifest itself in

92 Article 48, The Constitution of the People's Republic of China (1982, last amended 2018).

93 Article 12, Labour Law of the People's Republic of China (1994).

94 For example, on the implementation of the principle of equal opportunities and equal treatment of men and women in matters of employment and occupation, Article 19 has required all Member States of the European Union to place the burden of proof in their national law on the alleged perpetrator to show that the discrimination did not occur. See European Parliament, European Union Directive, 5 July 2006, 2006/54/EC, online: <http://eur-lex.europa.eu/legalcontent/EN/ALL/?uri=CELEX\%3A32006L0054 >

95 Concluding observations on the second periodic report of China, including Hong Kong, China, and Macao, China, CESCR, E/C.12/CHN/CO/2, (2014) para.14.

96 Ibid, para.14.

97 For similar definitions, see Article 1, International Convention on the Elimination of All Forms of Racial Discrimination, 21 December 1965, GA Res 2106(XX) (entered in to force 4 January 1969). See also Article 1, Convention on the Elimination of All Forms of Discrimination Against 
violence and harassment. ${ }^{98}$ As is pointed out by the CEDAW Concluding Observations to China, "the domestic legislation contains no comprehensive definition of discrimination against women that is in line with article 1 of CEDAW." ${ }^{99}$ Indeed, many Chinese legal provisions explicitly prohibit discrimination, yet the definition of discrimination is never further elaborated. Such a void in the legal system causes many difficulties in the application of anti-discrimination provisions and in the offering of adequate remedies. This is particularly true in China, where many cases filed with a discrimination claim were not even admitted by courts, let alone adequately addressed and redressed on the basis on non-discrimination. ${ }^{100}$ That is why China is urged to adopt a clear definition of discrimination in its national laws to make sure that all people are protected against discrimination, or at least could be adequately remedied when their equal rights are infringed. ${ }^{10}$

\section{Indirect Discrimination as a Legal Concept Missed in the Legal System}

It is requested by the CEACR of ILO in its examination of the implementation of ILO No.111 in China that "a distinction between direct or indirect discrimination [needs] to be clarified in domestic legislation to ensure that workers are protected against both direct and indirect discrimination”. ${ }^{102}$ In the current Chinese law, there is no legal provision that touches upon such a distinction. According to the definition offered in the treaty bodies' opinion, direct discrimination occurs when a less favourable treatment is given to an individual based on a prohibited ground, whenever there is a comparable, similar situation. For example, when a pregnant woman is dismissed from her work because of her pregnancy status, although there is no comparable situation of a 'pregnant male', such a dismissal is still a discriminatory act based on gender. ${ }^{103}$

Women, 18 December 1979, A/RES/34/180 (entered into force 3 September 1981). See also Article 2, Convention on the Rights of Persons with Disabilities, 13 December 2006, A/RES/61/106, Annex I.

98 UN Committee on the Elimination of Discrimination Against Women (CEDAW), General Recommendation No. 19: Violence against women, (1992).

99 Concluding observations on the combined seventh and eighth periodic reports of China, 7 November 2014, CEDAW/C/CHN/CO/7-8, para.12. See also Concluding comments of the Committee on the Elimination of Discrimination against Women: China, CEDAW/C/CHN/CO/6, 7-25 August 2006, para.9.

100 ILO, Sichuan University, Human Rights Centre, $A$ Selection of Cases in the Chinses Courts and Tribunals on anti-discrimination in Employment (Beijing: ILO, 2011), 3.

101 Concluding observations on the combined seventh and eighth periodic reports of China, CEDAW/C/CHN/CO/7-8, 7 November 2014, para.13.

102 ILO CEACR, Direct Request to China, on Discrimination (Employment and Occupation) Convention, 1958 (No. 111), 102 ILC Sess, (2013) para.2.

103 General comment No. 20: Non-discrimination in economic, social and cultural rights (Article 2, para. 2, of the International Covenant on Economic, Social and Cultural Rights), 2 July 2009, CESCR, E/C.12/GC/20, para.10. 
Indirect discrimination occurs when the seemingly neutral condition, treatment or criterion is applied to everyone, but in effect, it disproportionately impacts some people with certain characteristics. ${ }^{104}$ For example, in the case of domestic helpers, who are often excluded from joining local labour unions, there can be a combination of direct discrimination against their occupation and of indirect discrimination against women, who predominately compose the population of domestic servants. With a clear definition of indirect discrimination in law and detailed instruction, a judge can easily decide about a discriminatory offence hiding behind a seemingly innocent action and offer appropriate remedies to the victim.

\section{Discriminatory Geound of 'Social Origin' Missed in the Legal System}

As to the list of prohibited grounds in law, race, ethnicity, gender and religious belief as prohibited grounds are explicitly mentioned by the Chinese Labour Law, but workers with agricultural hukou are not included in the list of prohibited grounds of discrimination in the Labour Law system. ${ }^{105}$ Discrimination based on social origin, as is suggested by the ILO CEACR Direct Request to China, is the situation in which an individual's membership of a social class determines that individual's occupational future or accessibility to certain jobs. ${ }^{106}$ The condition of discrimination based on one's agricultural hukou status in China could well be included as a type of discrimination based on social origin. ${ }^{107}$ But the Chinese labour law fails to include social origin as one of the prohibited grounds for discrimination and thus fails to accordingly provide adequate redress. ${ }^{108}$

Since the establishment of hukou system in 1958, policy discrimination against people with agricultural hukou has been implicitly endorsed de jure and de facto. The 1958 law on hukou system itself builds a wall between the urban areas and the rural areas, making China one country but two societies. During the 1960s to 1980s, the government provided sufficient subsidies for the city dwellers from cradle to grave, extracting all the agricultural produce from the rural areas. During this time, governments placed strict restrictions on the movement of farmers to the cities in order

104 International Labour Office, General Survey concerning fundamental Conventions concerning rights at work in light of the ILO Declaration on Social Justice for a Fair Globalization, (Geneva: ILO, 2012), paras. 743 and 745.

105 Ronald C. Brown, “China’s Employment Discrimination Laws During Economic Transition” (2006) 19 Columbia Journal of Asian Law, 422.

106 International Labour Office, General Survey concerning fundamental Conventions concerning rights at work in light of the ILO Declaration on Social Justice for a Fair Globalization, (Geneva: ILO, 2012), para.7.

107 Ibid, para.802.

108 ILO CEACR, Direct Request to China, on Discrimination (Employment and Occupation) Convention, 1958 (No. 111), 102 ILC Sess, (2013) paras. 1 and 7. 
to ensure enough human resources for agricultural production to sustain the industrial production in the cities. Such rural-urban segregation has remained almost untouched until today and has been the basis of inferior treatment towards agricultural hukou holders in almost all aspects of life, as is elaborated in the second part of the paper.

Unequal treatment of rural migrant workers in terms of employment opportunities, working conditions, pension plans, accessibility to education of their children, still prevails in large cities. ${ }^{109}$ This is in contrast with efforts by the government to reform hukou policies around the country and has abolished many regulations that restricted rural migrant workers being employed transregionally. Additionally, many Chinese laws, such as the Employment Promotion Act of the People's Republic of China, provides that "governments at the county level are encouraged to direct more surplus rural workers into the urban areas and welcome them with improved working environment", ${ }^{110}$ such laws are seldom carried out in practice. The migrant workers from rural areas continue to be de facto discriminated against within working conditions, social security, health care and education. ${ }^{111}$ There is neither law explicitly prohibiting such discrimination based on social origin, nor is such discrimination wiped out in reality. Thus, it is not only necessary to incorporate non-discrimination based on hukou status, but also essential to adopt legislative or administrative measures to tackle de facto hukou discrimination, or discrimination based on social origin. Radically, and perhaps controversially, this paper suggests that that the hukou system be eventually abolished and laws be introduced to make sure that all rural-to-urban migrants are able to enjoy the work opportunities, as well as social security, housing, health and education benefits, on an equal footing with urban hukou holders. ${ }^{112}$

\section{Multiple Discrimination Missed in the Legal System}

To achieve truly realized equality in society, it is not enough just to eliminate singlebased discrimination, such as gender discrimination, or racial discrimination, or discrimination based on social origin. Discrimination is not necessarily revealed by distinctive external features, as many people may be subject to discrimination based on more than one ground. ${ }^{113}$ Take rural migrant women working as domestic helpers as an

109 Concluding observations on the second periodic report of China, including Hong Kong, China, and Macao, China, 13 June 2014, CESCR, E/C.12/CHN/CO/2, para.24.

110 Article 20, ibid.

111 Concluding observations on the second periodic report of China, including Hong Kong; China, and Macao, China, 13 June 2014, CESCR, E/C.12/CHN/CO/2, para.15.

112 Ibid.

113 International Labour Office, General Survey concerning fundamental Conventions concerning rights at work in light of the ILO Declaration on Social Justice for a Fair Globalization, (Geneva: ILO, 2012), para.748. 
example. They are inclined to suffer from gender discrimination, discrimination based on their social origin (agricultural hukou) and occupation-specific discrimination. ${ }^{114}$ Furthermore, such multiple levels of discrimination may manifest themselves in different forms and in different situations, which could not be dealt with by a singlebased approach to discrimination, or by offering a remedy simply by identifying one comparator. ${ }^{115}$ Hence, it is proclaimed by the CEDAW Observation that China shall make efforts to eliminate intersecting forms of discrimination. ${ }^{116}$ Nonetheless, addressing multiple discrimination by means of legislation or through the judiciary indeed remains a practical challenge. In China, intersectionality as a legal analysis tool, though recommended by most human rights treaty bodies to be applied in the process of legislation and adjudication, hardly remains a concern or focus.

\section{Equal Pay for Work of Equal Value Not Clarified in Law}

As expressed by the CEDAW Committee, the situation of women workers in the labour market raises concerns, including the lack of legal provisions ensuring "equal pay for equal work and work of equal value", "gender wage gap, a high percentage of women working in the informal sector, the harmful working conditions certain women workers might be exposed to..." ${ }^{117}$ Similarly, as observed by the CESCR Committee, despite the adoption of the Programme for the Development of Chinese Women (2011-2020), gender disparities prevail in practice in fields of employment, wages, housing and access to public services. ${ }^{118}$ Indeed, "equal pay for work of equal value” as an international principle of equal remuneration in the labour market has not yet been clarified in the Chinese labour law. Gender segregation in the labour market happens as a result of the social stereotypes about women's personality, capability, and preference. Thus, women are found predominantly in certain jobs, such as those in the informal sector and in caring business, which are often undervalued and unstable in

114 See Qinxuan Peng, "No Country for the Low-end? -An Intersectional Analysis of the Status of Migrant Women Workers as Domestic Helpers and Relevant Laws in China", (2019)26 International Journal on Minority and Group Rights at1-25.

115 Suzanne B. Goldberg, "Discrimination by Comparison", (2010) 9185 Columbia Public Law \& Legal Theory Working Papers, 29.

116 Concluding observations on the combined seventh and eighth periodic reports of China, 7 November 2014, CEDAW/C/CHN/CO/7-8, para.46. See also Concluding comments of the Committee on the Elimination of Discrimination against Women: China, 7-25 August 2006, $\mathrm{CEDAW} / \mathrm{C} / \mathrm{CHN} / \mathrm{CO} / 6$, para.27.

117 See Concluding comments of the Committee on the Elimination of Discrimination against Women: China, 7-25 August 2006, CEDAW/C/CHN/CO/6, paras. 29-30. See also Concluding observations on the combined seventh and eighth periodic reports of China, 7 November 2014, CEDAW/C/CHN/CO/7-8, para.36.

118 Concluding observations on the second periodic report of China, including Hong Kong, China, and Macao, China, 13 June 2014, CESCR, E/C.12/CHN/CO/2, para.16. 
comparison with "male jobs". ${ }^{119}$ The situation of rural migrant women typify such gender and hukou segregation: women often perform as domestic helpers due to the preformed social attitudes towards women, whereas rural migrant women working as domestic ${ }^{120}$ Viewed from a gender and intersectional perspective, the reason behind any payment gap is that the determination of wages fails to take into consideration any issue-related qualifications, but relies on sex-based or social origin-based distinctions.

There are many provisions to safeguard "equal remuneration" in the Chinese legal system. But they fail to reach the core of the issue by further clarifying the concept of "work of equal value", which is the primary condition of equal remuneration ${ }^{121}$ and the cornerstone of the ILO Convention No.100. ${ }^{122}$ In accordance with Articles 33 and 48 of the Constitution, "women ... enjoy equal rights with men in all spheres of life, in political, economic, cultural, social and family life" and the State ensures "equal pay for equal work to men and women alike”. In a similar vein, Article 46 of the 1994 Labour Law and Article 11 of the 2007 Labour Contract Law both refer to "equal pay for equal work'. But these principles will remain dead words on paper if such an equal pay principle is not founded on the basis of "work of equal value." This means that equal work remuneration is granted to men and women as long as the jobs they perform are of equal value.

Measuring the value of the varieties of jobs depends on an objective evaluation system for work values free from gender bias or any other forms negative stereotype. This means the way to examine the value of a certain job relies on objective criteria, like the skills involved, labour intensity, responsibilities, and working conditions. ${ }^{123}$ That said, a simple prohibition of sex-based wage discrimination is insufficient if it does not capture the concept of "work of equal value". ${ }^{124}$ In order to establish the principle of 'work of equal value', much needs to be done to reconstruct the current evaluation system for work. For example, a job evaluation system without gender-bias needs to be

119 International Labour Office, General Survey concerning fundamental Conventions concerning rights at work in light of the ILO Declaration on Social Justice for a Fair Globalization, (Geneva: ILO, 2012), para. 673.

120 See Qinxuan Peng, "No Country for the Low-end? - An Intersectional Analysis of the Status of Migrant Women Workers as Domestic Helpers and Relevant Laws in China", (2019)26 International Journal on Minority and Group Rights at1-25.

121 See Direct Request to China, on Equal Remuneration Convention, 1951 (No. 100), ILO CEACR, 102 ILC session, (2013) Article 1(b) of the Convention.

122 International Labour Office, General Survey concerning fundamental Conventions concerning rights at work in light of the ILO Declaration on Social Justice for a Fair Globalization, (Geneva: ILO, 2012), 281.

123 Direct Request to China, on Equal Remuneration Convention, 1951 (No. 100), ILO CEACR,102nd ILC session, (2013).

124 International Labour Office, General Survey concerning fundamental Conventions concerning rights at work in light of the ILO Declaration on Social Justice for a Fair Globalization, 2008 (Geneva: ILO, 2012), 283. 
established as a pre-requisite to achieving a labour market with equal remuneration for work of equal value. Many implementation gaps between IHRL/ILO standards on non-discrimination and the Chinese municipal law have been identified by the previous paragraphs and ultimately, the legal protection of human rights in the Chinese New Era still has a long march to go.

\section{CONCLUSION}

The Legal Protection of Human Rights has been listed as a priority on the agenda of the New Era. The paper characterizes the vast implementation gaps a "Long March" in truly realizing authentic, legal protection of human rights in China. Much work is required to bridge the gap between the current Chinese domestic legal system on tackling discrimination and the requirements set by the international human rights treaties and the international labour conventions. The paper concludes by asserting that China still lacks a comprehensive set of discrimination law as is suggested by the CESCR treaty body opinions, and there is no clear definition of discrimination that could be found in the current Chinese municipal laws that facilitates court applications and judicial remedies. Furthermore, indirect discrimination as a legal concept is not adopted in the current Chinese law and social origin as a prohibited ground of discrimination is not institutionalized in the current Chinese legal system. These dynamics result in de facto structural discrimination against rural migrant workers. Multiple dimensions of discrimination is not brought under the attention of Chinese domestic law and finally, "equal pay for work of equal value", a higher standard than mere "equal remuneration", is not yet given legal expression by the current Chinese law. Such conclusion is drawn by comparing the derived implications of the ratified international human rights treaties and international labour conventions on nondiscrimination and the existing Chinese domestic laws, referring to the provisions of the China-ratified IHRL and ILO conventions and their treaty bodies' observations. The implementation gaps this paper has identified are by no means exhaustive but serve as a primary foundation for further research. After all, the understanding of the distance between the aspiration and the reality is the very first step to make social engineering in this aspect.

\section{BIBLIOGRAPHY}

A. Bayefsky, "The Principle of Equality or Non-discrimination in International Law," (1990) 11: Human Rights Journal.

BBC Chinese, "A Safety Campaign after the Fire in Daxing District of Beijing, Official 
Media Denied Evacuation of Low-End Population" (24 November 2017), online: www.bbc.com/zhongwen/simp/world-42113608.

BBC, "Beijing Housing Block Fire: Nineteen People Killed" (19 November 2017), online: 〈http://www.bbc.com/news/world-asia-china-42043640>.

Charter of the United Nations, 1 UNTS XVI, UN (1945).

China Digital Times, "Sensitive Word of the Week: Low-end Population" (30 November 2017), <chinadigitaltimes.net/2017/11/sensitive-word-week-low-endpopulation/>.

China Media Project, "The Making of the Low-end Population" (30 November 2017), online: <http://chinamediaproject.org/2017/11/30/the-official-origins-of-low-endpopulation/>.

Christa Tobler, Indirect Discrimination, A case study into the Development of the Legal Concept of Indirect Discrimination under the EC Law (Antwerp, Oxford: Intersentia, 2005).

Constitution of the International Labour Organisation, ILO (1919).

Convention concerning Discrimination in Respect of Employment and Occupation, 25 June 1958, ILO, C111.

Convention concerning Equal Remuneration for Men and Women Workers for Work of Equal Value, 29 June 1951, ILO.

Convention on the Elimination of All Forms of Discrimination Against Women, 18 December 1979, A/RES/34/180 (entered into force 3 September 1981).

Convention on the Rights of Persons with Disabilities, 13 December 2006, A/RES/61/106, Annex I.

Dagmar Schiek, "Indirect Discrimination”, in Dagmar Schiek et al, Cases Materials and Texts on National, Supranational and International Non-discrimination Law (Oregon: Hart Publishing, 2007).

Declaration Concerning the Aims and Purposes of the International Labour Organisation, ILO (1944).

Declaration on Fundamental Principles and Rights at Work, ILC, 86 Sess, (1998).

Direct Request to China, on Equal Remuneration Convention, 1951 (No. 100), ILO 
CEACR, 102 ILC session, (2013) Article 1(b) of the Convention.

European Parliament, European Union Directive, 5 July 2006, 2006/54/EC, online: <http://eur-lex.europa.eu/legal-content/EN/ALL/?uri=CELEX\%3A32006L0054 >

European Union Agency for Fundamental Rights, European Court of Human Rights, Handbook on European Non-Discrimination Law (Strasbourg: Council of Europe Publishing, 2011).

Fang.com, "An Overview of the Real Estate Property Purchase Limit Policies in various cities 2018” (22 May 2018), online: <https://news.fang.com/open/28524435.html>.

General Recommendation No. 13: Equal remuneration for work of equal value, CEDAW (1989).

Ifeng News, "Court ruled apology for the first time for gender discrimination case," (22 September 2016), online: <http://wemedia.ifeng.com/282574491706821/wemedia.shtml>

Ifeng News, "Sitting in College Entrance Examination in Shanghai? You Need a Shanghai hukou First," (30 December 2012) online: < http://news.ifeng.com/mainland/detail_2012_12/30/20671337_0.shtml>.

ILO CEACR, Direct Request to China, on Discrimination (Employment and Occupation) Convention, 1958 (No. 111) (2012).

ILO CEACR, Direct Request to China, on Discrimination (Employment and Occupation) Convention, 1958 (No. 111), 102 ILC Sess, (2013).

ILO CEACR, Direct Request to China, on ILO Convention concerning Discrimination in Respect of Employment and Occupation, 1958(No. 111), 99 ILC Sess, (2010).

ILO CEACR, Observation concerning Equal Remuneration Convention (No. 100), ILC, 97 ILC Sess, (2008).

ILO, Declaration on Fundamental Principles and Rights at Work, adopted by the International Labour Conference at its Eighty-sixth Session, Geneva, 18 June 1998.

ILO, Sichuan University, Human Rights Centre, A Selection of Cases in the Chinses Courts and Tribunals on anti-discrimination in Employment (Beijing: ILO, 2011). 
International Convention on the Elimination of All Forms of Racial Discrimination, 21 December 1965, GA Res 2106(XX) (entered in to force 4 January 1969).

International Council on Human Rights Policy, Human Rights Standards: Learning from Experience (Switzerland: Versoix, 2006).

International Covenant on Civil and Political Rights, 16 December 1966, 16 December 1966, GA Res 2200A (XXI) (entered into force on 23 March 1976).

International Covenant on Economic, Social and Cultural Rights, 16 December 1966, GA Res 2200A (XXI) (entered into force on 3 January1976).

International Labour Office, General Survey concerning fundamental Conventions concerning rights at work in light of the ILO Declaration on Social Justice for a Fair Globalization, (Geneva: ILO, 2012).

Jianfa Shen and Wei Xu, "Migration and Development in China: Introduction", (2016).

Jing Song, "Mobility and Life Chances in Urbanization and Migration in China: Introduction, (February 2018).

Kam Wing Chan, "The Household Registration System and Migrant Labour in China: Notes on a Debate," (2010)36:2 Population and Development Review.

Labour Law of the People's Republic of China (1994).

Leontine Bijleveld, "Domestic Work in The Netherlands: A Job Like No Other" (2015) European Equality Law Review.

Lisa A. Crooms, "Indivisible Rights and Intersectional Identities or, What Do Women's Human Rights Have to Do with the Race Convention?” (1997) 619:40 Howard Law Journal.

Liu Shuhong, "Only 22\% Of Rural Migrant Workers Are Covered by Work Injury Insurance, Legal Daily (15 August 2009), online: <http://www.legaldaily.com.cn/0801/2009-08/15/content_1138656.htm>

National Bureau of Statistics of People's Republic of China, The 2017 Investigation and Survey Report on the National Migrant Workers, (Beijing: 27 April 2018), online :<http://www.stats.gov.cn/tjsj/zxfb/201804/t20180427_1596389.html>.

National Bureau of Statistics of People's Republic of China, The 2014 Investigation and Survey Report on the National Migrant Workers, (Beijing: 29 April 2015), online: <http://www.stats.gov.cn/tjsj/zxfb/201504/t20150429_797821.html>. 
National Bureau of Statistics of People's Republic of China, The 2015 Investigation and Survey Report on the National Migrant Workers, (Beijing: 28 April 2016), online: <http://www.stats.gov.cn/tjsj/zxfb/201604/t20160428_1349713.html>.

National Bureau of Statistics of People's Republic of China, The 2016 Investigation and Survey Report on the National Migrant Workers, (Beijing: 28 April 2017), online: <http://www.stats.gov.cn/tjsj/zxfb/201704//t20170428_1489334.html>.

Non-discrimination in economic, social and cultural rights (Article 2, para. 2, of the International Covenant on Economic, Social and Cultural Rights), CESCR, E/C.12/GC/20 (2009).

Non-discrimination in economic, social and cultural rights, 2 July 2009, E/C.12/GC/20].

Pan Jiahua and Wei Houkai, Blue Book of Cities in China: Annual Report on Urban Development in China No.5, first edition (Beijing: Social Science Academic Press, 2012).

People's Republic of China, including Hong Kong and Macao, CESCR, E/C.12/1/Add.107 (2005).

Political and Public Life No. 23, A/52/38, CEDAW (1997).

Promoting mutually beneficial cooperation in the field of human rights, UNHRC, A/HRC/37/L.36 (2018).

$\mathrm{Pu} \mathrm{Hao}$ and Shuangshuang Tang, "Floating or Settling Down: Effect of Rural Landholdings on the Settlement Intention of Rural Migrants in Urban China," (2015) 47 Environment and Planning.

Qinxuan Peng, "Multi-layered Gaps between ILO Conventions and Chinese Legal System", Bulletin for Comparative Labour Relations-89, Kluwer Law Business, 2015 .

Qinxuan Peng, "No Country for the Low-end? -An Intersectional Analysis of the Status of Migrant Women Workers as Domestic Helpers and Relevant Laws in China", International Journal on Minority and Group Rights (2019).

Resolution concerning the situation in Afghanistan, UNSC, S/RES/2344 (2017).

Ronald C. Brown, "China's Employment Discrimination Laws During Economic Transition” (2006) 19 Columbia Journal of Asian Law. 
seventh and eighth periodic reports of China, 7 November 2014, CEDAW/C/CHN/CO/7-8, 7 November 2014.

Suzanne B. Goldberg, "Discrimination by Comparison”, (2010) 9185 Columbia Public Law \& Legal Theory Working Papers.

The Constitution of the People's Republic of China (1982, last amended 2018).

The Convention on the Elimination of All Forms of Discrimination against Women, on temporary special measures, CEDAW, (2004).

The Convention on the Elimination of All Forms of Discrimination against Women, CEDAW/C/GC/28, CEDAW, (2010).

The Employment Discrimination in China, Current conditions and anti-Discrimination Strategies (Beijing: China Social Science Press, 2011).

The Equal Right of Men and Women to the Enjoyment of All Economic, Social and Cultural Rights (Article 3 of the Covenant), CEACR, E/C.12/2005/4, (2005).

The rights of migrant workers in an irregular situation and members of their families, UNCMW, CMW/C/GC/2, (2013).

The second periodic report of China, including Hong Kong, China, and Macao, CESCR, E/C.12/CHN/CO/2, (2014).

The State Council Information Office of the People's Republic of China, New Progress in the Legal Protection of Human Rights in China (Beijing: 2017).

The Supreme People's Court of the People's Republic of China, Report On the Work of the Supreme People's Court (Beijing: 2017).

The Committee on the Elimination of Discrimination against Women: China, CEDAW/C/CHN/CO/6, 7-25 August 2006.

Timo Makkonen, Multiple, Compound and Intersectional Discrimination: Bringing The Experiences of the Most Marginalized to the Fore, Institute for Human Rights (Turku: Åbo Akademi University Press, 2002).

UN Committee on the Elimination of Discrimination Against Women (CEDAW), General Recommendation No. 19: Violence against women, (1992).

UN General Assembly, International Covenant on Economic, Social and Cultural Rights, 16 December 1966, United Nations Treaty Series, vol. 993. 
Universal Declaration of Human Rights, GA Res 217 A (III), UNGA, UN Doc A/810(1948).

World Bank, "Labour Force," (15 February 2017), online: <http://data.worldbank.org/indicator/SL.TLF.TOTL.IN /countries.

Xi Jinping's report at 19th CPC National Congress - China - Chinadaily.com.cn", China Daily (4 November 2019), online: <http://www.chinadaily.com.cn/china/19thcpcnationalcongress/2017/11/0 4/content_34115212.htm>.

Xinhua News, "Female candidate was rejected to be employed as a chef, court ruled a written apology from the restaurant," (22 September 2016), online: <http://www.gd.xinhuanet.com/newscentre/2016-09/22/c_1119604273.htm>

Ying Peng, "Full text of Beijing Declaration adopted by the First South-South Human Rights Forum", Xinhua News (8 December 2017), online: <http://www.xinhuanet.com/english/2017-12/08/c_136811775.htm>.

Zhang Huafeng, "An Economic Analysis of Residence Requirements and Employment Discrimination," in Li Weiwei and Lisa Stearns, Employment Discrimination: International Standards and National Practice (Beijing: Law Press, 2006).

Zhang Yonghong, "Politics of Local Governance: A Systemic Perspective, Using the Implementation of Policies on the Protection of Rural Migrant Workers as an Example,” (2009) 49:1 Journal of Sun Yat-sen University, Social Science Edition.

Qinxuan Peng holds a PhD degree of law from Utrecht University. She is associate researcher at the China Top Think Tank Wuhan University International Law Institute, editor of Wuhan University International Law Review (Wuhan), researcher at the Cross-Cultural Human Rights Centre of Free University of Amsterdam (Amsterdam), Vice-Chair of the Association for Post-doc Researchers at Wuhan University(Wuhan), Secretary General to the Wuhan University Alumni Association Benelux (Kvk-registered, the Hague). 